\title{
An Exploratory Study to Assess the View and Progress of Alumni of Selected School and College of Nursing in Mumbai
}

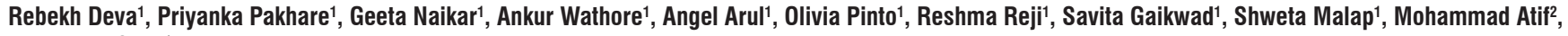 \\ Jayashree Salvi ${ }^{1}$ \\ ${ }^{1}$ Department-Community Health Nursing, K.J.Somaiya College of Nursing, Sion, Mumbai, Maharashtra, India, ${ }^{2}$ Department-Medical Surgical Nursing, Assistant \\ Professor, K.J.Somaiya College of Nursing, Sion, Mumbai, Maharashtra, India
}

\section{Abstract}

Aim: An exploratory study to assess the view and progress of alumni of selected school and college of nursing in Mumbai.

Materials and Methods: The study population consisted of 60 alumni and was divided into two groups consisting of 30 subjects each. These alumni were the ones who had completed their GNM and bachelors nursing course until 2017. The study data were collected using telephonic interview. The study tool was initially validated and reliability of the tool was also performed. The study data were presented as frequency and percentages.

Results: The demographic variables of the study population show that out of 30 samples were conducted. In old alumni, all did the diploma and $63.3 \%$ in new alumni. Importantly, work profile, $80 \%$ of the old alumni and $73.33 \%$ of new alumni work in clinical. Of 60 samples, $3.33 \%$ of old and new alumni work in institution (teaching) and $16.66 \%$ of old alumni in other jobs.

Of 30 samples, maximum views of the new alumni about physical infrastructure, classroom, teaching, clinical experiences, evaluation system, and discipline are very good of new alumni $(56.66 \%)$ and old alumni about knowledge, skills, and attitude acquired by student are very good, good, and fair (33.33\%). The maximum views of the new alumni about cooperation from non-teaching and supporting staff, about available facilities of library, student guidance and support, internet facility, and extracurricular activities, are rated as excellent and very good and maximum views of the old alumni are good (33.33\%).

Conclusion: The investigators learnt that old alumni have progressed more than the new alumni.

Keywords: New alumni, nursing college, old alumni, progress

\section{INTRODUCTION}

Universities are responsible for the disseminating and transferring of knowledge, as well as for providing specialized human resources. Furthermore, they continually required to analyze and update their services, and to identify problems and challenges to allow them to optimize educational quality.

The ongoing educational assessment of different scientific disciplines is critical, particularly for medical sciences. Educational assessment helps to identify constraints and

\begin{tabular}{|l|}
\hline \multicolumn{1}{|c|}{ Access this article online } \\
\hline Website: http://innovationalpublishers.com/Journal/ijnmi \\
\hline ISSN No: $2656-4656$ \\
DOI: $10.31690 /$ ijnmi/49 \\
\hline
\end{tabular}

obstacles, and to solve problems and identify strengths and weaknesses. The results of such assessments allow positive aspects to be upheld and effective solutions for potential problems to be implemented. ${ }^{[1]}$

Many studies have indicated a need for the nursing education system to keep pace with continuous changes in nursing practice. The literature suggests that the results of apprenticeship are not satisfactory, which is indicated the need for more attention to this aspect. ${ }^{[2]}$ Although new nursing graduates possess a strong theoretical background and knowledge, they do not have the necessary skills and dexterity which are required to solve problems that arise in clinical settings. Some studies have also indicated the existence of a vast gap between classical nursing and obstetric education and clinical care performance, suggesting that the present clinical education system does not provide students with the

Address for Correspondence:

Mrs. Jayashree Salvi, Vice-Principal, Department of Community Health Nursing, K. J. Somaiya College of Nursing, Sion, Mumbai, Maharashtra, India.

E-mail: jrsalvi1976@yahoo.com

This is an open-access journal, and articles are distributed under the terms of the Creative Commons Attribution Noncommercial Share Alike 4.0 License, which allows others to remix, tweak, and build upon the work non-commercially, as long as appropriate credit is given and the new creations are licensed under the identical terms 
necessary clinical skills. ${ }^{[3]}$ The results of research on various clinical aspects indicate that students consider the quality of the education to be unsatisfactory. Reported deficits were including the instructors' inabilities to apply theoretical principles in practical situations, inconsistency of apprenticeships in clinical wards, students being compelled to do other unrelated tasks, lack of proper evaluation by instructors, and a lack of congruence between theoretical learning and the clinical nursing services. ${ }^{[3]}$

Studies in other countries have also identified that a gap between theoretical learning and clinical nursing services is caused by clinical environment constraints, a lack of coordination between clinical settings and educational institutes, an obscure role for nursing instructors, defects in curriculum planning, and the clinical performance and role of the lecturers. ${ }^{[4]}$

Although the nursing students spend a long time in clinical settings, this cannot guarantee educational quality alone because many variables influence the learning outcomes including the student's personality, the clinical teachers and their skills, the ward personnel and their willingness to cooperate with the students, interpersonal relationships, attitudes, equipment, physical structure, and hierarchical relations, as well as other factors in the educational environment that is recognized in organizational and educational theories. ${ }^{[5]}$ The development and promotion of nursing education requires continuous monitoring for correcting weaknesses, and students as the outputs of this education are the best who identify these educational problems.

Alumni-based evaluations are increasingly recognized as an important part of the process of ongoing curriculum of the institute. Alumni relation is an important part of an institution's advancement activities for many reasons such as they are institutions' most loyal supporters and generate valuable word of mouth among their social and professional networks. They are great role models for current students and are often well placed to offer practical support to students as they start their careers.

Alumni are a vital part of the institute. The words and feedback of the alumni toward institute play a key role in assessing the efficiency of institution and also to know about the strength and weakness of the institution. Hence, the progressive step can be taken toward the development and success of the institution.

The beliefs and activities have taken a greater change toward modernization and development, through sharing of various individuals' views and ideas. Hence, it is also important to consider the views and ideas of alumni to know the development of the institution in every aspect such as educational, clinical, and training programme. Hence, the student can step forward toward success.

Hence, alumni are international ambassadors. They take their knowledge given by institution to their hometown and countries and into their professional and social networks.
Few studies have determined the nursing alumni views of their educational problems and limitations; therefore, the current study was aimed to explain the experiences and views and progress of nursing alumni of K. J. Somaiya College of Nursing, Sion, Mumbai.

\section{Materials and methods}

The study population consisted of 60 alumni of K. J. Somaiya College of Nursing, Sion, Mumbai. The population was divided into two groups consisting of 30 subjects each. These alumni were the ones who had completed their GNM and bachelors nursing course until 2017. The study data were collected using telephonic interview. The study tool was initially validated and reliability of the tool was also performed. The study data were presented as frequency and percentages.

\section{RESULTS}

\section{Demographic variables}

Table 1 shows demographic variables of the study population. Of 30 samples of the old alumni, majority (90\%) of people belong to the age group of 26-35 years. It shows that of 30 samples of the new alumni, majority (70\%) of people belong to the age group of 16-25 years. Of 30 samples, majority $(60 \%)$ of people are male in old alumni. It shows that of 30 samples, majority $(63.33 \%)$ of people are female in new alumni. Of 30 samples, the whole group (100\%) has done diploma course in old alumni. Of 30 samples, majority $(63.3 \%)$ of the people has done diploma course in new alumni. Of 30 samples, majority ( $80 \%$ ) of the old alumni work in clinical. Of 30 samples, majority $(73.33 \%)$ of the new alumni work in clinical. Of 60 samples, $3.33 \%$ of old and new alumni work in institution (teaching). Of 30 samples, $16.66 \%$ of old alumni has been positioned as application specialist, business development

Table 1: Demographic variables

\begin{tabular}{|c|c|c|}
\hline \multirow[t]{2}{*}{ Particulars } & Old alumni $(n=30)$ & New alumni $(n=30)$ \\
\hline & Frequency (\%) & Frequency (\%) \\
\hline \multicolumn{3}{|l|}{ Age (years) } \\
\hline $16-25$ & $0(0)$ & $21(70)$ \\
\hline $26-35$ & $27(90)$ & $9(30)$ \\
\hline $36-45$ & $2(6.67)$ & $0(0)$ \\
\hline $46-55$ & $1(3.33)$ & $0(0)$ \\
\hline \multicolumn{3}{|l|}{ Gender } \\
\hline Male & $18(60)$ & $11(36.66)$ \\
\hline Female & $12(40)$ & $19(63.33)$ \\
\hline \multicolumn{3}{|l|}{ Education } \\
\hline BSc nursing & $0(0)$ & $11(36.66)$ \\
\hline GNM & $30(100)$ & $19(63.33)$ \\
\hline \multicolumn{3}{|l|}{ Year of passing } \\
\hline Before 2012 & $30(100)$ & $0(0)$ \\
\hline After 2012 & $0(0)$ & $30(100)$ \\
\hline \multicolumn{3}{|l|}{ Designation } \\
\hline Clinical & $24(80)$ & $22(73.33)$ \\
\hline Institutional & $1(3.33)$ & $1(3.33)$ \\
\hline Any other & $5(16.66)$ & $7(23.33)$ \\
\hline \multicolumn{3}{|c|}{ Years of experience } \\
\hline Teaching & $1(3.33)$ & $1(3.33)$ \\
\hline Clinical & $29(96.67)$ & $29(96.67)$ \\
\hline
\end{tabular}


manager, etc. Of 30 samples, $23.33 \%$ of new alumni has been positioned as student, not working, etc. [Table 1].

\section{Feedback}

Of 30 samples, maximum views of the new alumni about physical infrastructure are excellent $(40 \%)$ and maximum views of the old alumni are good (53.33\%). Of 30 samples, maximum views of the new alumni about classroom teaching are very good $(60 \%)$ and maximum views of the old alumni are rated as very good and good (36.67\%). Of 30 samples, maximum views of the new alumni about clinical experience are $\operatorname{good}(36.66 \%)$ and maximum views of the old alumni are good (36.67\%). Of 30 samples, maximum views of the new alumni about evaluation system are very good $(43.33 \%)$ and maximum views of the old alumni are good $(56.67 \%)$. Of 30 samples, maximum views of the new alumni about discipline are very good (53.33\%) and the maximum views of the old alumni are excellent (36.67\%). Of 30 samples, maximum views of the new alumni are very good $(56.66 \%)$ and the maximum views of the old alumni about knowledge, skills, and attitude acquired by student are very good, good, and fair (33.33\%). Of 30 samples, maximum views of the new alumni about value-added education are very good (50\%) and maximum views of the old alumni are very good $(36.67 \%)$.

Of 30 samples, maximum views of the new alumni about cooperation from non-teaching and supporting staff are very good $(46.66 \%)$ and maximum views of the old alumni are excellent (40\%). Maximum views of the new alumni about available facilities of library are very good (40\%) and maximum views of the old alumni are good (56.67\%). Maximum views of the new alumni about student guidance and support are rated as excellent and very good (36.66\%) and maximum views of the old alumni are good (36.67\%). Maximum views of the new alumni about internet facility are rated as very good $(36.66 \%)$ and maximum views of the old alumni are poor $(76.67 \%)$. Maximum views of the new alumni about extracurricular activities are rated as excellent and very good (43.33\%) and maximum views of the old alumni are good (33.33\%).

Old alumni also showed interest by paying 1 student fees $(3.33 \%)$ and the new alumni have shown interest by paying 1 student fees $(3.33 \%)$. Old alumni also showed interest by taking one free lecture to the students $(73.33 \%)$ and new alumni shown interest (36.66\%). Old alumni have shown interest by providing books to the library (30\%) and the new alumni have shown interest (40\%). Old alumni had also shown interest by giving articles for the laboratory (10\%) and new alumni shown interest (20\%) [Table 2].

\section{Progress and development of alumni}

Of 30 samples, majority $(43.33 \%)$ of the old alumni have completed their diploma in nursing and of 30 samples, majority $(53.33 \%)$ of the new alumni have done completed their diploma in nursing. Majority $(46.67 \%)$ of old alumni

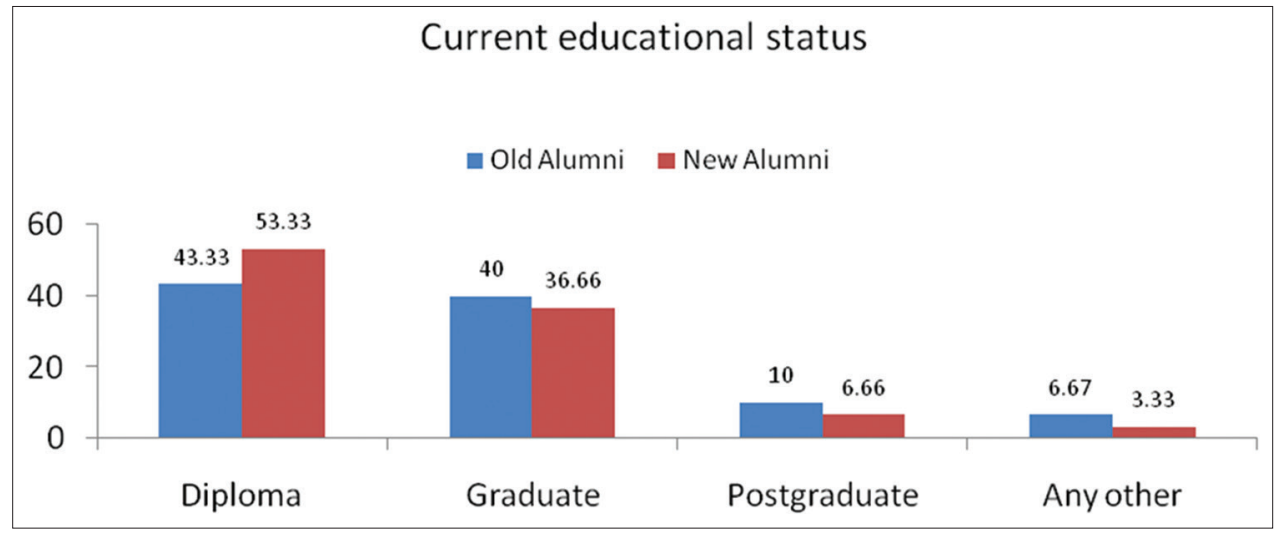

Figure 1: Of 30 samples, majority (43.33\%) of the old alumni and (53.33\%) of the new alumni have completed their diploma in nursing

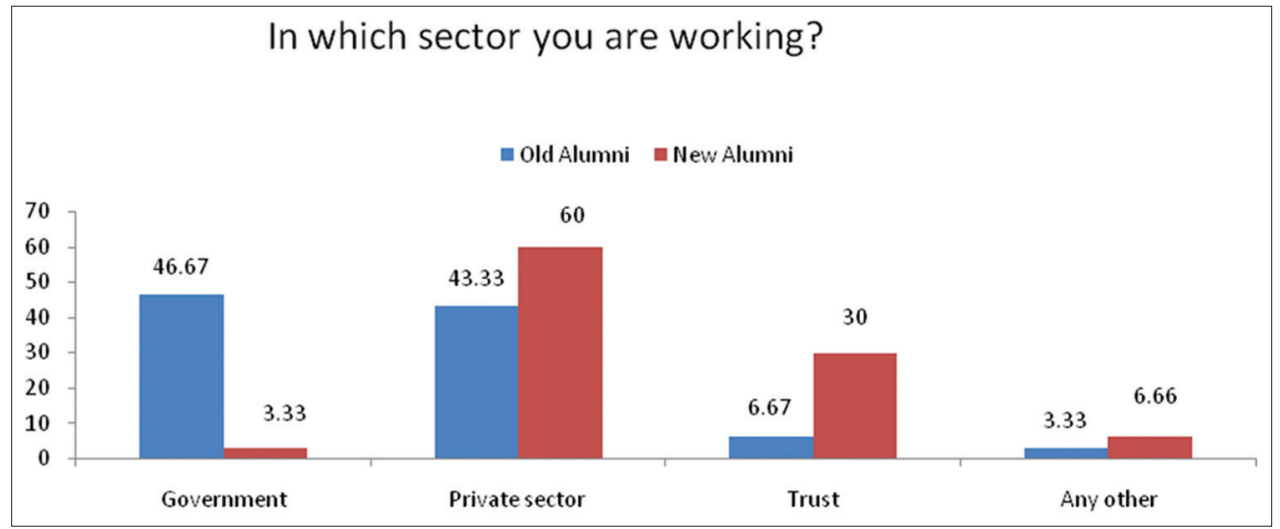

Figure 2: Of 30 samples, majority (46.67\%) of old alumni works in government sector which (60\%) majority of the new alumni works in private sector 


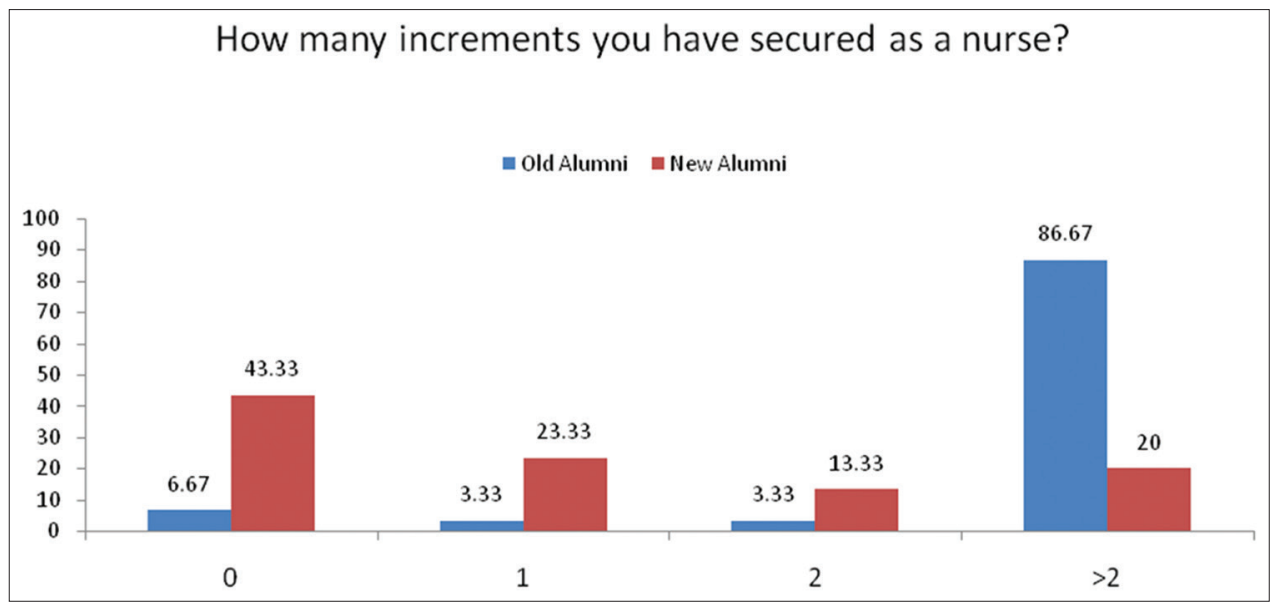

Figure 3: Of 60 samples, $86.67 \%$ of the old alumni has maximum increments than new alumni

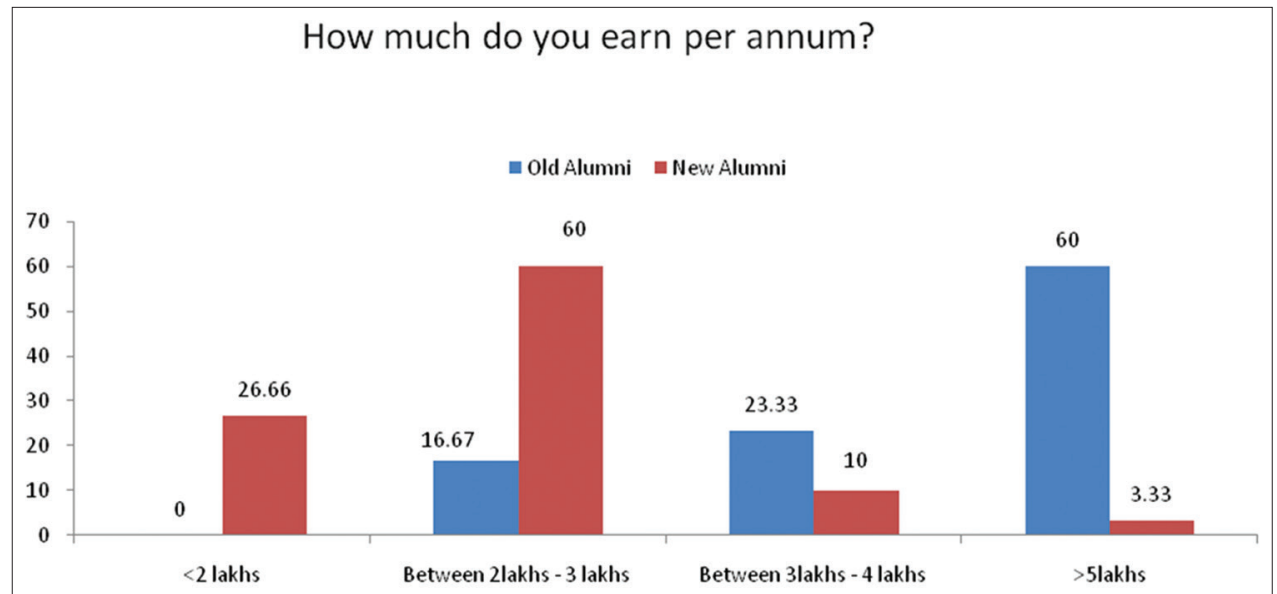

Figure 4: Of 30 samples, majority of the new alumni (60\%) earns between 2 and 3 lakhs and 3 and 4 lakhs per annum and $60 \%$ of the old alumni earns $>5$ lakhs per annum

works in government sector and $(60 \%)$ majority of the new alumni works in private sector. $86.67 \%$ of the old alumni have maximum increments than new alumni [Figures 1 and 2].

Majority of the new alumni (60\%) earns between 2 and 3 lakhs and 3 and 4 lakhs per annum. Majority (60\%) of the old alumni earns $>5$ lakhs per annum [Figures 3 and 4].

About $16.65 \%$ of old alumni and $10 \%$ of new alumni have completed their research studies. $96.67 \%$ of old alumni and $96.67 \%$ of new alumni published no research paper, while, $3.33 \%$ subjects in each group, published one paper. $66.67 \%$ of old alumni and $86.66 \%$ of new alumni attended $<5$ CNEs. $13.33 \%$ of old alumni received nest nurse award and $6.66 \%$ of new alumni received the best employee award [Figures 5-8].

\section{Discussion}

This study aimed to evaluate the views and feedback of the alumni of a nursing college that provides undergraduate education. The study also aimed to provide data for the quality studies of this institution. Therefore, it was to be expected that the participants were mainly service nurses or nurses in charge of services who also participated in patient care. Considering the alumni ages and professional and corporate experience, this study showed that young and inexperienced alumni were mainly employed in clinical as expected. Similar results have been reported by Altuntaş and Baykal. ${ }^{[6]}$

A majority of the alumni felt that they had excellent and very good professional knowledge, professional ideals and expectations, and problem-solving and critical thinking skills. This nursing college is quite successful in terms of the number of nurse instructors and their academic achievements and titles. Since this institution has completed its structuring and created own institutional culture to some extent, has been in a good position regarding the number and quality of instructors, and reached a certain level in terms of educational quality, it is a role model and guide for the other nursing schools. In addition, this nursing school is in a continuous effort to improve the training they provide.

It is an expected situation that both old and new alumni consider themselves different, which is a positive finding for this educational institution. 


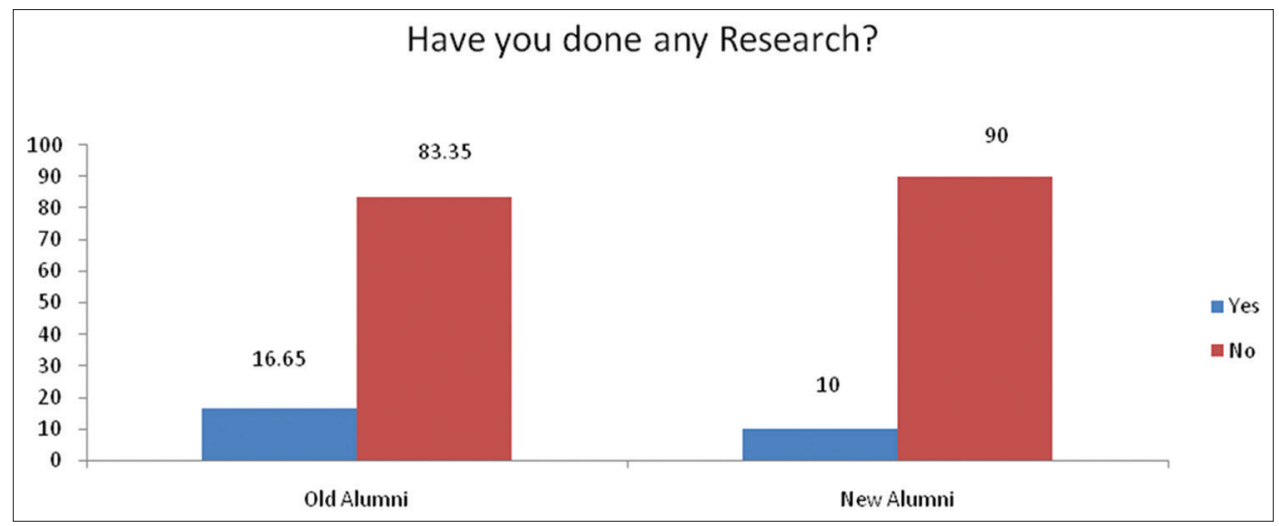

Figure 5: Of 60 samples, majority of the group has done any research (old alumni [83.35\%] and new alumni [90\%])

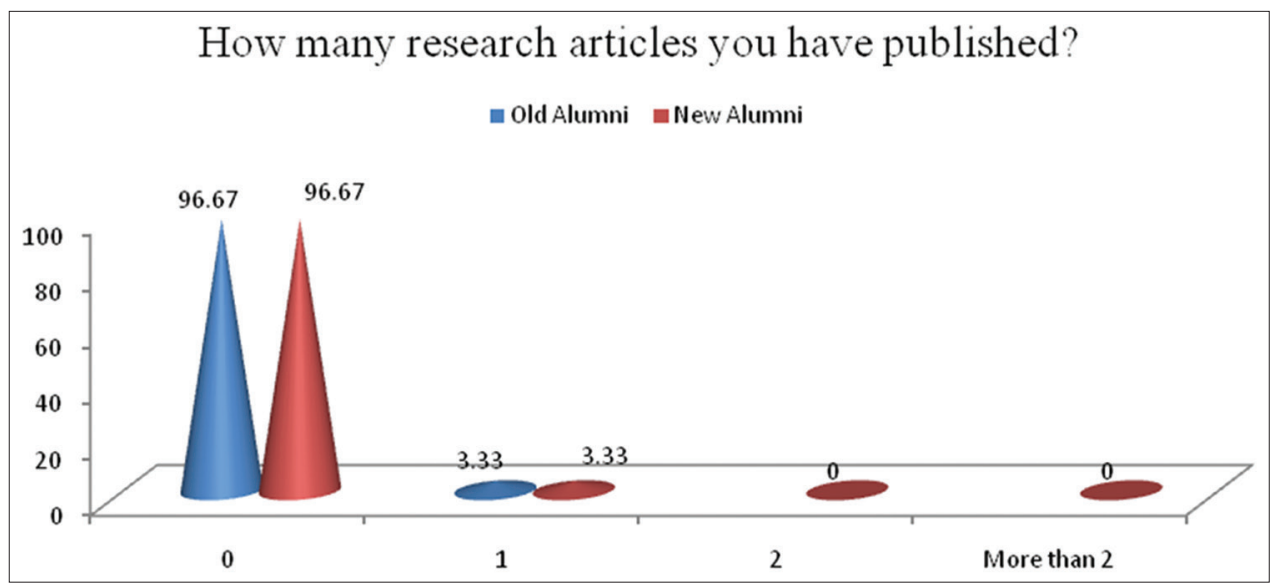

Figure 6: Of 60 samples, majority of the group have not published any research (old alumni [96.67\%] and new alumni [96.67\%]). Moreover, only $3.33 \%$ of the old and new alumni have published research

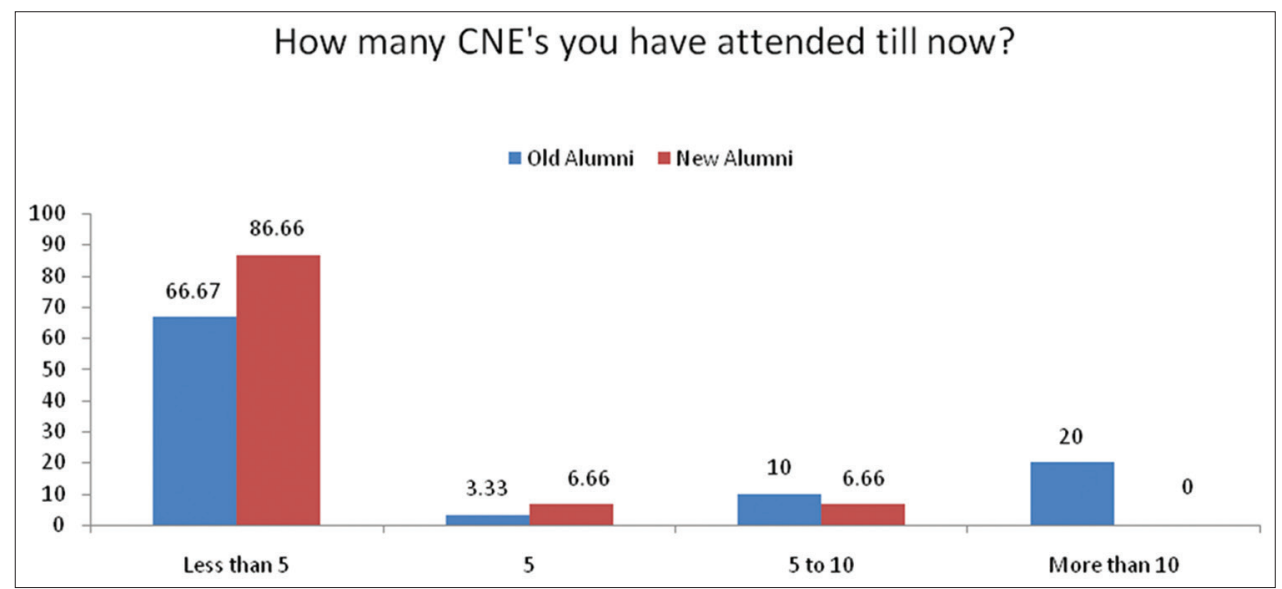

Figure 7: $0 f 60$ samples, majority of the group have attended $<5$ CNEs (old alumni $\{66.67 \%\}$ and new alumni [86.67])

In 2017, a study was conducted by Altuntaş and Baykal ${ }^{[6]}$ studied 314 alumni who worked as bedside nurses in 36 Istanbul hospitals, and 314 evaluations by the 195 nurse managers who supervised them. In the study, overview of the alumni performance evaluations showed that the alumni regarded themselves strong in practice, personal traits, and teamwork and communication. Their managers also thought that the alumni had stronger practices, personal traits, and teamwork and communication.
This study's findings show that both the old and new alumni had weakest association with their research. This finding is contradictory to the study conducted with the students of the nursing faculty determined that the students considered themselves sufficient in putting research results into practice (97.6\%) and doing studies for their professional development $(96.4 \%){ }^{[7]}$ These findings imply that the nurses could not sufficiently use the knowledge and skills they learned in their undergraduate education 


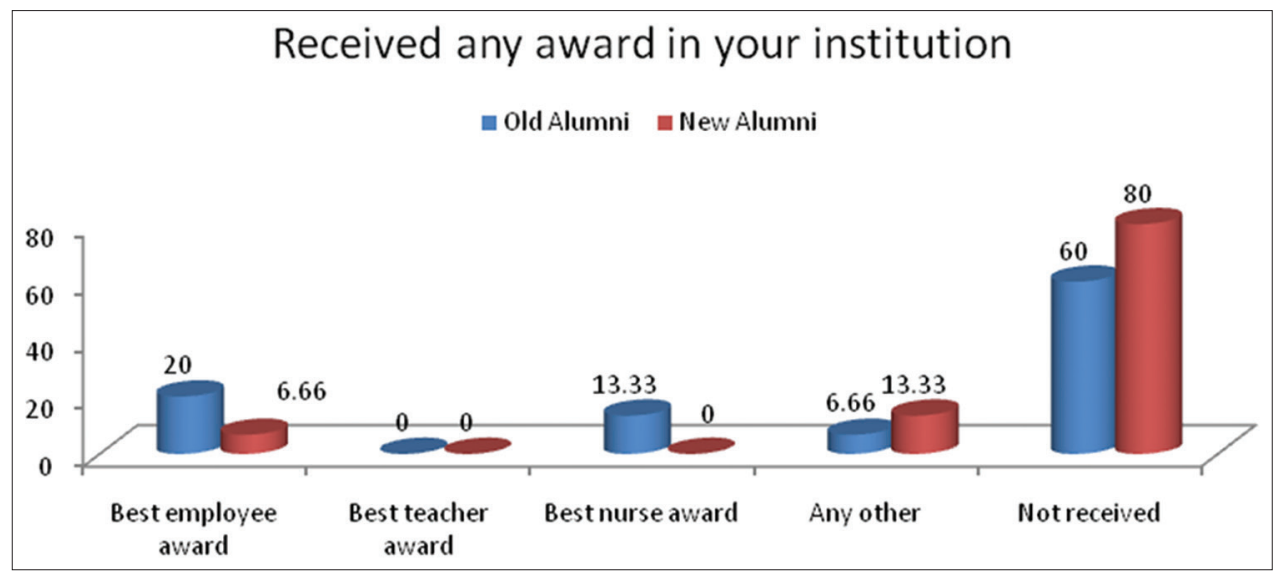

Figure 8: Of 30 samples, majority (20\%) of the old alumni have received the best employee award. Table 2 shows that out of 30 samples, majority $(13.33 \%)$ have received many other awards in their institutions

Table 2: Feedback and views of the old and new alumni

\begin{tabular}{|c|c|c|c|c|c|c|c|c|c|c|}
\hline \multirow[t]{3}{*}{ Parameter } & \multicolumn{5}{|c|}{ Old alumni $(n=30)$} & \multicolumn{5}{|c|}{ New alumni $(n=30)$} \\
\hline & EX & VG & G & $\mathbf{F}$ & $\mathbf{P}$ & EX & VG & G & $\mathbf{F}$ & $\mathbf{P}$ \\
\hline & $F(\%)$ & $F(\%)$ & $F(\%)$ & $\mathbf{F}(\%)$ & $F(\%)$ & $\mathbf{F}(\%)$ & $\mathbf{F}(\%)$ & $F(\%)$ & $\mathbf{F}(\%)$ & F (\%) \\
\hline Physical infrastructure & $3(10)$ & $6(20)$ & $16(53.33)$ & $5(16.67)$ & $0(0)$ & $12(40)$ & $11(36.66)$ & $6(20)$ & $1(3.33)$ & $0(0)$ \\
\hline Classroom teaching & $7(23.33)$ & $11(36.67)$ & $11(36.67)$ & $1(3.33)$ & $0(0)$ & $10(33.33)$ & $18(60)$ & $2(6.67)$ & $0(0)$ & $0(0)$ \\
\hline Clinical experience & $10(33.33)$ & $8(26.67)$ & $11(36.67)$ & $1(3.33)$ & $0(0)$ & $10(33.33)$ & $8(26.66)$ & $11(36.66)$ & $1(3.33)$ & $0(0)$ \\
\hline $\begin{array}{l}\text { Evaluation system } \\
\text { (examination and } \\
\text { assignment) }\end{array}$ & $5(16.67)$ & $7(23.33)$ & $17(56.67)$ & $1(3.33)$ & $0(0)$ & $8(26.66)$ & $13(43.33)$ & $9(30)$ & $0(0)$ & $0(0)$ \\
\hline Discipline & $11(36.67)$ & $10(33.33)$ & $7(23.33)$ & $2(6.67)$ & $0(0)$ & $5(16.66)$ & $16(53.33)$ & $9(30)$ & $0(0)$ & $0(0)$ \\
\hline $\begin{array}{l}\text { Knowledge, skills, } \\
\text { and attitude acquired } \\
\text { by students }\end{array}$ & $9(30)$ & $10(33.33)$ & $10(33.33)$ & $1(3.33)$ & $0(0)$ & $8(26.66)$ & $17(56.66)$ & $5(16.66)$ & $0(0)$ & $0(0)$ \\
\hline $\begin{array}{l}\text { Value-added } \\
\text { education }\end{array}$ & $4(13.37)$ & $11(36.67)$ & $10(33.33)$ & $4(13.33)$ & $1(3.33)$ & $8(26.66)$ & $15(50)$ & $7(23.33)$ & $0(0)$ & $0(0)$ \\
\hline $\begin{array}{l}\text { Cooperation from } \\
\text { non-teaching/ } \\
\text { supportive staff }\end{array}$ & $12(40)$ & $8(26.67)$ & $9(30)$ & $1(3.33)$ & $0(0)$ & $13(43.33)$ & $14(46.66)$ & $3(10)$ & $0(0)$ & $0(0)$ \\
\hline $\begin{array}{l}\text { Facilities available: } \\
\text { Library }\end{array}$ & $4(13.33)$ & $6(20)$ & $17(56.67)$ & $2(6.67)$ & $1(3.33)$ & $10(33.33)$ & $12(40)$ & $7(23.33)$ & $1(3.33)$ & $0(0)$ \\
\hline $\begin{array}{l}\text { Student guidance and } \\
\text { support }\end{array}$ & $5(16.66)$ & $9(30)$ & $11(36.37)$ & $4(13.33)$ & $1(3.33)$ & $11(36.66)$ & $11(36.66)$ & $8(26.66)$ & $0(0)$ & $0(0)$ \\
\hline Internet facility & $0(0)$ & $2(6.67)$ & $2(6.67)$ & $3(10)$ & $23(76.67)$ & $5(16.66)$ & $11(36.66)$ & $6(20)$ & $2(6.66)$ & $6(20)$ \\
\hline $\begin{array}{l}\text { Extracurricular } \\
\text { activities and support }\end{array}$ & $4(13.33)$ & $8(26.66)$ & $10(33.33)$ & $4(13.33)$ & $4(13.33)$ & $13(43.33)$ & $13(43.33)$ & $2(6.66)$ & $1(3.33)$ & $0(0)$ \\
\hline
\end{tabular}

after they start working for a variety of reasons. Some relevant studies have found that nurses had low rates of participating in the studies conducted in their work environment, ${ }^{[8]}$ keeping up with the nursing literature, putting research results into practice and that they encountered corporate barriers to participation in studies. ${ }^{[8]}$ Another study of nursing students found that students who did not think nurses did not keep up with the nursing literature or put research results into practice. ${ }^{[9]}$ A study by Hisar and Karadağ (2007) $)^{[10]}$ found that nurses' weakest side was research. This finding shows that nurses' research skills are not supported and developed sufficiently in their professional lives.

\section{ConcLusion}

The study explored the views and progress of the alumni in which during the data collection through telephonic interview, there were problems such as network issues, some were reluctant to give their personal information while most of them were cooperative and we were also not able to convey proper information through telephonic interview. The investigators learnt that old alumni have progressed more than the new alumni.

\section{RefERENCES}

1. Ziaee M, Miri M, Haji-abadi M, Azarkar G, Eshbak P. Academic staff and students' impressions on academic evaluation of students in Birjand university of medical sciences and health services. J Birjand Univ Med Sci 2006;13:9-15.

2. Adami MF, Kiger A. A study of continuing nurse education in Malta: The importance of national context. Nurs Educ Today 2005;25:78-84.

3. Hadizadeh F, Firoozi M, Razavi NS. Nursing and midwifery students perspective on clinical education in gonabad university of medical 
sciences. Iran J Med Educ 2005;5:70-8.

4. Corlett J. The perceptions of nurse teachers, student nurses and preceptors of the theory-practice gap in nurse education. Nurse Educ Today 2000;20:499-505.

5. Moattari M, Ramazani S. Nursing students' perspective toward clinical learning environment. Iran J Med Educ 2009;9:137-45.

6. Altuntaş S, Baykal Ü. An analysis of alumni performance: A study of the quality of nursing education. Nurse Educ Today 2017;49:135-9.

7. Kaya H, Tasocak G, Akcin E, Kisa B. Nursing college students' opinions about the college's achievement of its main goals. İstanbul Univ Florence Nightingale Nurs Coll J 2005;13:77-84.

8. Bahar Z, Gözüm S, Beşer A, Çapık C, Kıssal A, Aydoğdu N, et al. An analysis of the obstacles to research use of the nurses who work in two regions and the factors that influence them. Dokuz Eylül Univ Fac Nurs
Electr J 2015;8:232-40.

9. Cevahir R, Sözeri CU, Akduran FS, Şahin S, Çınar ND. The Opinions of Health College Students who Attended a Research Course about the use of Research Results in Clinical Practices. Izmir: The $3^{\text {rd }}$ International Nursing Congress Presentation Summary Book; 2005. p. 51.

10. Hisar F, Karadag A. Determining Nurse Managers' Professional Behaviors. Ankara: The $4^{\text {th }}$ International and Eleventh National Nursing Congress Presentation Summary Book; 2007. p. 213.

How to cite this article: Deva R, Pakhare P, Naikar G, Wathore A, Arul A, Pinto O, et al. An Exploratory Study to Assess the View and Progress of Alumni of Selected School and College of Nursing in Mumbai. Int J Nurs Med Invest. 2019;4(2):36-42. 